\title{
ĐÁNH GIÁ KẾT QUẢ SỚM PHẪU THUẠTT CẮT THÙY PHỔI VỚI ĐƯờNG MỞ NGỬC XÂM LẤN TỐI THIỂU TẠI BỆNH VIỆN VIỆT ĐỨC
}

\author{
Ngô Gia Khánh*, Đoàn Quốc Hung*, Phạm Hũu Lu**, Nguyễn Hũu Uớc**
}

\section{TÓM TẮT:}

Từ 6/2015 đến $11 / 2015$ có 30 bệnh nhân được phẫu thuật cắt thùy phổi qua đường mở ngực ít xâm lấn. 22 nam/8 nữ, tuổi trung bình 48 (32-70 tuổi). Trong đó: $21 \mathrm{BN}$ ung thư phổi, $2 \mathrm{BN}$ phổi biệt lập, $3 \mathrm{BN}$ giãn phế quản, $1 \mathrm{BN}$ u nấm phổi, 1 $\mathrm{BN}$ áp xe phổi, $2 \mathrm{BN}$ kén khí phổi lớn. Không có tử vong hay biến chứng lớn, thời gian phẫu thuật trung bình $150 \pm 30$ (phút), số $\mathrm{BN}$ truyền máu trong mổ 3 , thời gian rút dẫn lưu $4 \pm 1$ ngày, thời gian nằm viện $6 \pm 1$ ngày. Đường mổ ngực ít xâm lấn là đường mổ khả thi, hiệu quả, an toàn trong phẫu thuật cắt thùy phổi, có thể khắc phục một số hạn chế của đường mổ ngực sau bên kinh điển.

Tù khóa: Mở ngục it xâm lấn

\section{SUMMARY:}

Short term result of minimally invasive thoracotomy for lung lobectomy at Viet Duc hospital. From 1/2015 to $9 / 2015,30$ patients were operated with minimally invasive surgery. There were 22 males, 8 females, mean age was 48 years (range 32-70). Surgical indication was lung cancer 21, pulmonary sequestration 2 , bronchiectasis 3 , aspergillomas 1, lung abscess 1, primary pneumothorax 2. No mortality or major morbidity were recorded, operating time was $150 \pm 30$ (minutes), intraoperative blood transfusion was in 3 patients, duration of chest tube drainage was $4 \pm 1$ (days), length of hospital stay was $6 \pm 2$ (days). We have demonstrated that the minimally invasive thoracotomy was feasible, safe, effective procedure for perfoming lobectomy, it restricted standard posterolateral disadvantages.

Key words: Minimally invasive thoracotomy

\section{I. ĐẠT VẤN ĐỀ}

Phẫu thuật cắt thùy phổi là kỹ thuật kinh điển điều trị một số bệnh lý đường hô hấp: ung thư phổi, giãn phế quản khu trú, kén khí lớn, áp xe phổi mãn tính...Cắt thùy phổi với đường mở ngực sau bên ngày càng ít được áp dụng do nhiều biến chứng (đau nhiều, thẩm mỹ, tăng nguy cơ nhiễm trùng, tổn thương thần kinh...) và dần được thay thế bằng các kỹ thuật xâm lấn tối thiểu [2]. Phẫu thuật nội noi cắt thùy phổi có nhiều ưu điểm, tuy nhiên do giá thành đắt nên hiện nay vẫn chưa được áp dụng rộng rãi. Phẫu thuật cắt thùy phổi với đường mở ngực xâm lấn tối thiểu (là đường mở ngực với chiều dài đường rạch dưới $8 \mathrm{~cm}$ không cắt cơ [4]) giúp hạn chế các biến chứng của phẫu thuật mổ mở kinh điển mà không làm tăng chi phí phẫu thuật. Nghiên cứu này nhằm tổng kết kết quả bước đầu áp dụng kỹ thuật này tại Bệnh viện Việt Đức

\section{II. ĐỐI TƯợng VÀ PHƯớG PHÁP NGHIÊN CÚ'U}

2.1 Đối tượng: Mô tả cắt ngang hồ sơ các $\mathrm{BN}$ phẫu thuật cắt thùy phổi bằng đường mở ngực xâm lấn tối thiểu tại Khoa Phẫu thuật Tim mạch Lồng ngực Bệnh viện Việt Đức từ tháng 6/2014 - 11/2015.

2.2 Phương pháp nghiên cứu. Mô tả các dấu hiệu lâm sàng, kỹ thuật mổ, kết quả sớm sau mổ bàn luận có so sánh với các tác giả khác.

\subsection{Quy trình phẫu thuật}

- Chuẩn bị bệnh nhân:

+ Tư thế: Bệnh nhân nằm nghiêng $90^{\circ}$. Kê gối dưới lưng. Treo tay.

\footnotetext{
Khoa Phẫu thuật tim mạch và Kồng ngục Bệnh viện Việt Đức Ngưòi chịu trách nhiệm khoa học: PGS.TS. Đoàn Quốc Hung Ngày nhận bài: 05/04/2016 - Ngày Cho Phép Đăng: 05/05/2016 Phản Biện Khoa học: PGS.TS. Đặng Ngọc Hùng
} GS.TS. Bùi Đúc Phú 
+ Vị trí kíp mổ: Phẫu thuật viên đứng phía trước (phía bụng) BN. Phụ phẫu thuật đứng phía sau (phía lưng) BN. Dụng cụ viên đứng cùng bên với phẫu thuật viên.

- Gây mê: Gây mê toàn thân, nội khí quản thông khí chọn lọc một phổi

- Kỹ thuật: Rạch da 6 - 8cm đường ngực bên từ khoảng đường nách trước đến đường nách sau khoảng khoang liên sườn IV, V. Cắt qua tổ chức dưới da, lớp cân nông. Phẫu tích bó cơ lưng rộng theo chiều dọc rồi kéo ra phía sau. Phẫu tích bó cuối cùng của cơ răng trước rồi kéo ra trước.
Xác định khoang liên sườn: thông thường nếu mổ cắt thùy trên thì vào qua khoang liên sườn $\mathrm{IV}$, cắt thùy dưới vào qua khoang liên sườn $\mathrm{V}$. Cắt qua các cơ gian sườn để vào khoang màng phổi. Sử dụng 2 Finochietto: Finochietto thứ nhất làm rộng khoang liên sườn, Finochietto thứ 2 đặt vuông góc với Finochietto thứ nhất. Bộc lộ Tĩnh mạch, động mạch, phế quản rồi cắt như phẫu thuật kinh điển. Đóng vết mổ: tháo bỏ Finochietto, cầm máu mép vết mổ, không siết sườn, trả các cơ lưng rộng và cơ răng trước về vị trí cũ, khâu đóng vết mổ.

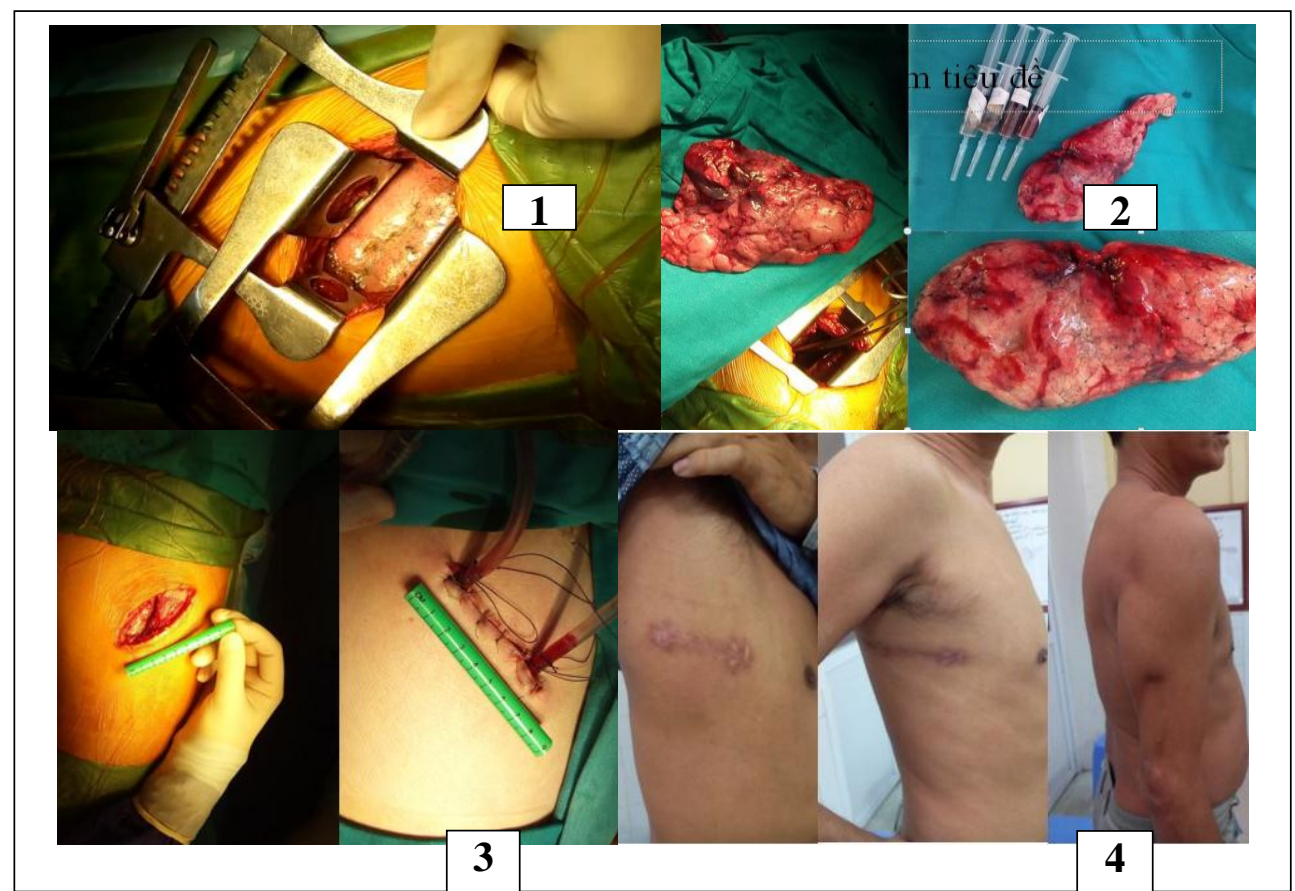

Hình 1: Đặt các Finochietto,

\section{Hình 3: Độ dài đường rach $(7,5 \mathrm{~cm})$}

\section{KẾT QUẢ:}

Từ 6/2015 - 11/2015 có 30 bệnh nhân đủ tiêu chuẩn nghiên cứu

-Đặc điểm đối tượng nghiên cứu: Nam/Nữ: 22/8, Tuổi trung bình 48 (tuổi)

-Đặc điểm giải phẫu bệnh: Adenocarcinoma của phổi 21, phổi biệt lập 2, Vách kén khí xơ hóa 2, Áp xe phổi 1, Giãn phế quản 3, U nấm Arpergilus 1

-Thời gian phẫu thuật trung bình $150 \pm 30$ (phút)

-Không có tử vong trong và sau mổ
Hình 2: Thùy phổi, hạch sau khi cắt

Hình 4: Bệnh nhân 1 tháng sau mổ

-Không có nhiễm trùng vết mổ

-Số bệnh nhân phải truyền máu trong mổ 5 (bệnh nhân)

-Số lượng dẫn lưu màng phổi trong ngày đầu tiên $180 \pm 50(\mathrm{ml})$

-Thời gian rút dẫn lưu màng phổi $4 \pm 1$ (ngày)

-Thời gian nằm viện $6 \pm 2$ (ngày)

\section{BÀN LUẬN}

-Phẫu thuật mổ mở với đường mở ngực sau 
bên là đường mở ngực tiêu chuẩn đã được áp dụng rộng rãi. Đường mổ này mang lại phẫu trường rộng, có thể tiếp cận xử lý tất cả các tổn thương của phổi trung thất. Tuy nhiên đường mổ này gây tổn thương cơ ngực do đó gây ra nhiều biến chứng sau mổ đáng kể là gây đau nhiều, giảm khả năng ho, giảm vận đông khớp vai, giảm chức năng phổi...

-Nhiều phương pháp phẫu thuật nhằm hạn chế tối đa tổn thương các cơ thành ngực đặc biệt là cơ lưng rộng và cơ răng trước đã được giới thiệu. Mở ngực đường nách được mô tả bởi Baeza, Foster và được phổ biến bởi Ginsberg. Đường mở ngực tách cơ được mô tả bởi Daniel $\mathrm{M}$. Bethencourt và cộng sự vào năm 1988[1]. Nó đã được ủng hộ như một biện pháp giảm đau sau mổ, bảo tồn chức năng phổi và làm giảm các biến chứng sau phẫu thuật. Một lợi ích khác của đường mổ này là trong những trường hợp có biến chứng rò phế quản sau mổ. Cơ lưng rộng và cơ răng trước được dùng như một vật liệu để đóng lỗ rò, điều này là khó thực hiện đối với đường mổ sau bên kinh điển[2]. Ngoài ra đường mổ này cũng đảm bảo yếu tố thẩm mỹ khi gần như toàn bộ đường rạch da được cánh tay che phủ.

-Trong nghiên cứu của chúng tôi, với đường rạch da tối thiểu không lớn hơn nhiều so với đường rạch da để lấy bệnh phẩm trong phẫu thuật cắt thùy phổi có nội soi hỗ trợ (VATS) (khoảng $5 \mathrm{~cm}$ ) cho phép thực hiện kỹ thuật một cách thuận lợi mà

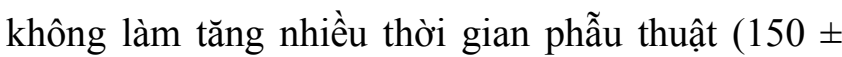
30 phút). So với đường mở ngực kinh điển, đường mở ngực không cắt cơ mất nhiều thời gian hơn để mở ngực 'opening time' tuy nhiên thời gian đóng ngực 'closing time' lại nhanh hơn do không phải thực hiện đường khâu cân cơ thành ngực. Thời gian thực tế phẫu thuật (từ lúc đặt đến lúc rút Finochietto) phụ thuộc vào từng phẫu thuật viên, đối với phẫu thuật viên quen với trường mổ nhỏ thì thời gian phẫu thuật cũng không lâu hơn so với đường mổ kinh điển [2].

-Benedetti đánh giá tình trạng đau ngực 1 tháng sau phẫu thuật chỉ ra rằng tổn thương thần kinh liên sườn là nguyên nhân dẫn đến đau kéo dài ở bệnh nhân sau mổ. Ông cũng nhận thấy rằng đường mở ngực sau bên liên quan đến tổn thương thần kinh liên sườn nhiều hơn là đường mở ngực tách cơ. Nhiều nghiên cứu cũng chỉ ra rằng, nguyên nhân gây tổn thương thần kinh liên sườn ở bệnh nhân sau mổ lồng ngực thường do 2 lý do: Finochietto chèn vào bó mạch thần kinh liên sườn trong quá trình mổ và động tác siết sườn (khâu giữa xương sườn trên và xương sườn dưới) với đường mổ nhỏ banh sườn ở mức tối thiểu và không siết sườn sau mổ có thể là lý do đường mổ không cắt cơ ít gây đau hơn [5].

-Akçali so sánh giữa hai kỹ thuật mở ngực kinh điển và mở ngực tách cơ nhận thấy: không có sự khác biệt về thời gian phẫu thuật, chức năng phổi, khả năng vận động khớp vai... trong tuần đầu tiên sau mổ với đường mở ngực không cắt cơ tốt hơn so với đường mở ngực kinh điển [6].

-Trong nghiên cứu của chúng tôi nhận thấy rằng, tuy thời gian rút dẫn lưu màng phổi không có sự khác biệt, tuy nhiên số lượng dịch ra theo dẫn lưu màng phổi trong ngày đầu tiên giảm hơn so với đường mở ngực kinh điển $180 \pm 50 \mathrm{ml}$, có thể do không cắt ngang cơ nên hạn chế được chảy máu từ thành ngực.

-Một ưu điểm nữa là chúng tôi không ghi nhận trường hợp nào bị nhiễm trùng vết mổ trong điều kiện chăm sóc, thay băng hàng ngày là không khác biệt. Với đường mở ngực sau bên kinh điển, với việc cắt ngang các cơ thành ngực sau đó khâu đóng lại vết mổ không thể tránh khỏi việc thiểu dưỡng và hoại tử một phần cơ ngực tại đường mở, điều này dẫn đến tăng nguy cơ nhiễm trùng vết mổ.

\section{KẾT LUẬN}

Đường mở ngực nhỏ không cắt cơ có thể thay thế đường mở ngực sau bên kinh điển trong các phẫu thuật cắt thùy phổi trong một số bệnh lý không làm kéo dài thời gian phẫu thuật, mà lại có nhiều ưu điểm hơn: ít đau hơn, phục hồi nhanh hơn, giảm tỉ lệ nhiễm trùng vết mổ, có tính thẩm mỹ hơn. 


\section{TÀI LIỆU THAM KHẢO}

1.Jesus Loscertales, Miguel Congregado, Sergio Moreno (2012), "Posterolateral thoracotomy without muscle division: a new approach to complex procedures", Interact Cardiovasc Thorac Surg, Jan; 14(1): 2-4.

2.Athanassiadi K, Kakaris S, Theakos N, Skottis I (2007), "Muscle-sparing versus posterolateral thoracotomy: a prospective study", Eur J Cardiothorac Surg, Mar;31(3)

3.Hazelrigg SR, Landreneau RJ, Boley TM, Priesmeyer M, Schmaltz RA (1991), “The effect of muscle-sparing versus standard posterolateral thoracotomy on pulmonary function, muscle strength, and postoperative pain", J Thorac Cardiovasc Surg, Mar;101(3): 394-400.
4.Ufuk Çobanoğlu, Özcan Hız, Mehmet Melek, Yeşim Edirne (2011), "Is muscle-sparing thoracotomy advantageous?", Türk Göğ̈̈s Kalp Damar Cer Derg; 19(1): 43-48 43

5.Mohamed A.F. Elshiekha, Tammy T.H. Lob, Alex R. Shipolinib and David J. McCormackb (2013), "Does muscle-sparing thoracotomy as opposed to posterolateral thoracotomy result in better recovery?", Interactive CardioVascular and Thoracic Surgery 16, 60-67.

6. Akçali Y, Demir H, Tezcan B (2003), “The effect of standard posterolateral versus muscle-sparing thoracotomy on multiple parameters", The Annals of thoracic surgery, 76:4 Oct pg 1050-4. 